\title{
BREACH OF PSYCHOLOGICAL CONTRACT AND QUALITY OF LIFE; PSYCHOSOMATIC STRAIN AS MEDIATOR AND POWER DISTANCE AS MODERATOR
}

\author{
MUHAMMAD ASAD \\ Capital University of Science and Technology, Islamabad, Pakistan
}

\begin{abstract}
This study empirically examined the impact of breach of psychological contract on employees' quality of life via the mediating mechanism of psychosomatic strain, while facilitating effect of power distance was also examined. Data were collected from a sample of 183 employees using a questionnaire. Results confirm that the breach of psychological contract declines employees' quality of life, while mediating role of psychosomatic strain in this particular relationship was also established. Contrary to expectations, power distance does not act as a moderating variable. Implications, limitation and future research direction are discussed.
\end{abstract}

\section{INTRODUCTION}

Psychological contracts form the core relationship between employee and employer in which employee expects equity and justice at workplace (Morrison \& Robinson, 1997; Hui, Lee \& Rousseau, 2004). However, these expectations are not always met causing breach of psychological contract (Bal et.al; 2008). Various negative outcomes are associated with feeling of breach of psychological contract, which include lack of trust, dissatisfaction from one's job, lack of affective commitment and decline in both in-role and extra role performance (Zhao, Wayne, Glibkowski and Bravo, 2007). Apart from psychological outcomes the breach of psychological contract can negatively affect employees' health causing psychosomatic strain (Gakovic \& Tetrick, 2003), which is generally caused by psychosocial stressors and symptoms including sleeplessness, headaches and fatigue.

The presence of psychosomatic strain at workplace (Ganster \& Rosen, 2013; Höge, 2009; Bauer, 2006) is associated with breach of psychological contract and such strain is associated with diabetes, depression and cardiovascular diseases (Ganster \& Rosen, 2013). It is imperative to find out how these factors affect employee well-being and quality of life, but limited literature addresses the issue. We argue that these factors negatively affect employee's quality of life as occupational stress has been reported to have negative impact upon employees' quality of life (Greenhaus, Collins \& Shaw, 2003; Yang et al., 2009) and subjective well-being (Sonnentag \& Zijlstra, 2006; De Jonge,
Bosma, Peter, \& Siegrist, 2000; Diener, 2000).

We further argue that breach of psychological contract varies across cultures (Kirkman, Lowe, \& Gibson, 2006; Chao, Cheung\& $\mathrm{Wu}, 2011$ ), as the studies in US and western cultures might not have same results in Asian countries (Restubog, Bordia \& Tang, 2007). Based on these studies we suggest that power distance can intensify the effect of perceived psychological breach in a way that in high power distance cultures like Pakistan; employees will experience a higher level of psychosomatic strain, which has also been concurred by Liu, Yang, \& Nauta (2013).

The current study is believed to contribute in psychological contract literature in two ways. It will relate breach of psychological contract with quality of life through the mechanism of psychosomatic strain. In addition, it will consider impact of power distance as potential moderator highlighting intensity of outcomes associated with breach of psychological contracts, which varies across cultures.

\section{LITERATURE REVIEW}

\section{Breach of Psychological Contract (BPC) and Quality of Life (QOL)}

The construct of psychological contract has been the focus of researchers for many years and there exists substantial amount of research on the nature of psychological contract, its evolution and the possible outcomes. Psychological contacts are at the heart of understanding employment relationships in various 
occupations (Rousseau, 1998; Coyle-Shapiro \& Kessler, 2000; Guest, 2004; Persson \& Wasieleski, 2015). A psychological contract represents an unwritten and implicit agreement between an employee and the organization about mutual obligations and is mainly based upon the perception of employer and employee about what they owe to each other (Robinson\& Rousseau, 1994; Rousseau, 1989). Therefore, the felt obligations on part of the employee and the employing organization represent a psychological contract. Typically, these obligations are not expressly written or placed in the formal employment contract (Guest, 2004; Rousseau, 2001).

Breach of psychological contract (BPC) is a condition when employee feels that the organization has failed to fulfill its obligations toward him or her and has not reciprocated positively to the contribution that has been made by that employee. Moreover, the employee feels that the organization didn't fulfill its promises despite being able to do so, which carries the element of willful violation on part of the employer (Robinson \& Morrison, 2000; Morrison \& Robinson, 1997). It gives rise to the feelings of disappointment, depression, frustration, and distress, in combination with feelings of anger, resentment, bitterness and outrage, resulting from the perceptions of betrayal (Priesemuth \& Taylor, 2016; Rigotti, 2009; Conway \& Briner, 2002).

Such perceived breach may lead to various work-related outcomes. Kickul and Lester (2001) reported negative affect towards the organization, reduced job satisfaction and $\mathrm{OCB}$ as the outcomes of BPC. Decline in performance and absenteeism are also reported to be linked with BPC (Restubog, Bordia \& Tang, 2006; Johnson \& O'Leary-Kelly, 2003; Matthijs Bal, Chiaburu \& Jansen, 2010; Suazo, Turnley, \& Mai, 2005). In their meta-analysis, Zhao et al. (2007) reported many negative outcomes of psychological contract breach including mistrust, reduced job satisfaction, decline in commitment, organizational citizenship behavior, performance and increased turnover intentions. A meta-analysis by Bal et al. (2008) also supported the negative link between BPC and work outcomes (trust, job satisfaction and commitment). Research also suggests a link between BPC and deviance at workplace (Restubog et al., 2015; Bordia, Restubog \& Tang 2008; Chiu \& Peng, 2008). Moreover, the perception of psychological contract breach can also result in diverting employees' commitment with their organizations to other entities and bodies like their respective unions (Bashir \& Nasir, 2013). It is evident from the existing literature of psychological contract breach that its work-related outcomes are studied substantively; still the effect of such breach on subjective well-being of employees represented in the form of quality of life remains a neglected area.

Broadly, quality of life represents a subjective evaluation and psychological state of individuals of their overall life circumstances (Abdel-Khalek, 2010; Costanza, 2007; Diener, 2000; Cella, 1994). There are no specific studies linking psychological contract breach and quality of life, yet the literature clearly has evidence that work-related variables in general have an impact upon quality of life of employees. Management practices and employment conditions that are adopted in the contemporary workplace may have the potential to either enhance or diminish quality of life (Boreham, Povey \& Tomaszewski, 2016). Additionally, a few studies indicate that BPC and similar variables have an impact upon employees' well-being. Therefore, we believe that BPC has its implications on employees' life consequences as well, since the work of Cassar \& Buttigieg (2015) reported negative consequences of BPC on emotional well-being. There is also some support of the negative relationship between BPC and well-being (De Jong et al., 2015; Cuyper, 2008). Furthermore, job insecurity (a feeling related to perceived breach) is a precursor of deteriorating well-being of employees (Silla et.al 2009; De Cuyper and De Witte, 2007). Hence, we hypothesize that:

\section{Hypothesis 1. Breach of psychological contract is negatively associated with employees' quality of life}

\section{Psychosomatic Strain as a Mediator between the Breach of Psychological Contract and Quality of Life}

Psychosomatic strain is generally caused by psychosocial stressors resulting in sleeplessness, headaches and fatigue, such stressors may be present in the workplace (Ganster \& Rosen, 2013; Höge, 2009; Bauer, 2006). For example, Nieuwenhuijsen, Bruinvels and Frings-Dresen (2010) noted the impact of high job demands, low job control, low co-worker support, low supervisor support, low procedural justice, low relational justice and a high effort-reward imbalance upon stress related disorders. Gakovic, A., \& Tetrick (2003) noted that employment exchange relationships play a role in the strain experienced by the employees and the breach of psychological contract is positively associated with such strain.

This can be explained from the perspective of affective events theory by Weiss and Cropanzano (1996), which predicts that negative events at 
workplace cause negative emotions like frustration, and anger, resulting in subsequent negative outcomes, also concurred by Morrison and Robinson (1997). Cropanzano and Mitchell (2005) further explained that the breach of psychological contract is a negative event according to social exchange theory, which shows an organization's failure to reciprocate employees' contribution. Theoretically integrating the breach of psychological contract and perceived organizational support, Aselage and Eisenberger (2003) suggested that BPC is linked with the perception of the failure of an organization in extending support to its employees, which results in negative reciprocation by the employees. Suazo and Stone-Romero (2011) also put forward such a view of BPC. Moreover, research suggests that psychological contract breach depicts a negative workplace event (Zhao et.al; 2007; Weiss \& Beal 2005; Kiefer 2005). Therefore, we argue that BPC as a negative event gives rise to negative emotions, which causes stress and further leading to negative outcomes to the affected employees.

It can be also viewed from the angle of trust. Since trust is the basic condition of employment relationship between employee and organization (Rousseau, 2001), and is also incorporated in all psychological contracts (Atkinson, 2007), the breach of psychological contract represents a situation of betrayal, promises being broken and expectations being unmet (Morrison \& Robinson 1997), which in any social relationship causes negative outcomes as trust breaks (Lewis \& Weigert 1985). Therefore, we believe that BPC results in reduced trust, which consequently results in the stress that the betrayed party experiences. As Troman (2000) noted that a low trusting social relationship results in stress among teachers. Costa, Roe, and Taillieu (2001) also indicated that a trusting environment reduces team members' stress and improve work outcomes. More specifically, there is a positive linkage between psychological contract fulfillment and mental health (Parzefall \& Hakanen 2010).

Strain arises from different sources and its life consequences including subjective well-being, life satisfaction and quality of life are associated with each other and these negative effects are well documented. Stress caused by negative life events including those associated with work results in declining life satisfaction (Marum, 2014). There exists a significant negative relationship between stress and life satisfaction (Hayes \& Weathington, 2007; Barnes \& Lightsey, 2005; Hamarat et al., 2001). Specifically, job stress is also responsible for lowering quality of life, as Min (2014) noted the negative impact of job stress upon quality of life. Similarly, Lerner et al. (1994) observed the negative effects of job strain upon health-related quality of life of employees. It appears that the stressors causing psychosomatic strain which are present at workplace can cause employees' quality of life to decline. Therefore, we argue that psychological contract breach can be a workplace stressor causing psychosomatic strain, which ultimately leads to reduced quality of life of employees; therefore, hypothesis two is developed as:

\section{Hypothesis 2. Psychosomatic strain mediates the relationship between psychological contract breach and quality of life}

\section{Power Distance as a Moderator between the Breach of Psychological Contract and Psychosomatic Strain}

Literature suggests that psychological contract is a culture-sensitive concept, which implies that the formation of psychological contracts, perception of their violation and responses to such violation are affected by the cultural profile of individuals (Kirkman, Lowe, \& Gibson, 2006; Thomas, Au \& Ravlin, 2003; Zhao \& Chen 2008; Kickul, Lester \& Belgio, 2004; Westwood, Sparrow \& Leung, 2001; Bochner \& Hesketh, 1994). An important dimension of culture affecting the responses to BPC is that of power distance, which is defined as the extent to which the less powerful members of institutions and organizations within a country expect and accept that power has been spread unequally (Hofstede, 1983). As Chao, Cheung and Wu (2011) noted the moderating effect of power distance between BPC and counterproductive work behaviors, such that it strengthens the impact. Similarly, Zagenczyk et al. (2015) found that power distance positively moderates the relationship between $\mathrm{BPC}$ and the responses towards it.

Additionally, the characteristics associated with high power distance at organizational level are centralized and autocratic decision making, highly personalized, strong leadership, limited delegation, bureaucratic controls and little empowerment (Lok \& Crawford, 2004; Joiner, 2001; Fikret, 2000; Robert, 2000). Zagenczyk et al. (2015) noted that if BPC occurs under high power distance cultures, then employees don't raise their voice against it and generally remain passive in their responses. Such silence and inability to communicate their concern to the seniors can become a source of stress (Milliken, Morrison \& Hewlin, 2003; Beer \& Eisenstat, 2000). Hence, we argue that employees are likely to remain 
passive against the breach of psychological contract in a high power distance culture and there arises a possibility of anxiety and unpleasant feelings amongst them, which is likely to enhance the psychosomatic strain associated with BPC.

Pakistani public sector organizations are high on the dimension of power distance, where the dependence of subordinates upon superiors is high and disagreement with them is uncommon and unwelcomed. There exists a centralized system with many hierarchical levels with minimal top to bottom communication and bottom-up communication is unheard of (Islam, 2004; Khilji, 2004; Khilji, 2002). Hence, we believe that under high power distance orientation, Pakistani public sector employees will experience a high level of stress if the breach of psychological contract occurs. And the subsequent hypothesis is:

Hypothesis 3. Power distance moderates the relationship between psychological contract breach and psychosomatic strain such that the strain will be intensified in the presence of high power distance and vice-versa

FIGURE 1 Theoretical Framework

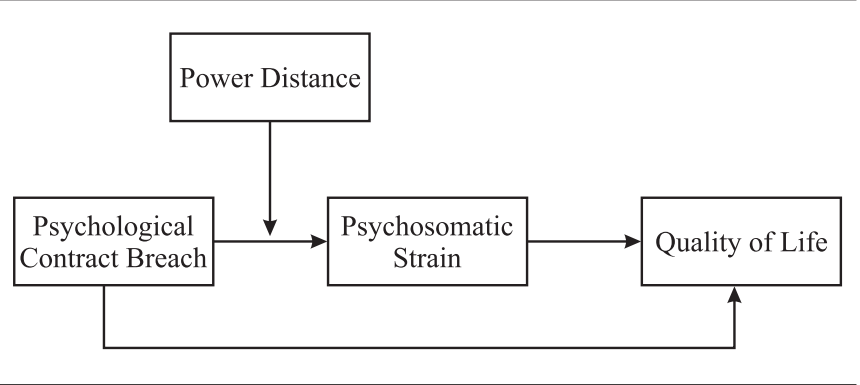

RESEARCH METHODOLOGY

\section{Sample and Population}

Purposive sampling technique was employed to contact respondents based on their willingness to participate in the survey. Questionnaires were distributed amongst survey respondents who were employed in different organizations, which include public sector organizations, banks and educational institutions. Only those respondents who gave their consent to participate in the study were finalized as participants. Out of 250 distributed questionnaires, 189 were initially received, representing a response rate of $75.6 \%$.

Out of 189 respondents, $123(65.07 \%)$ were males and $66(34.92 \%)$ were females. 86 respondents were from the age bracket of 21-30 years, 98 from 31-40 years and 5 were from 41 years and above age bracket i.e. $45.50 \%, 51.85 \%$ and $2.64 \%$ respectively. The mix of respondents in terms of total work experience was 44(1-5 years), 80 (6-10 years), 60 (11-15 years) and 5 (16 years and above) depicting $23.28 \%, 42.32 \%$, $31.74 \%$ and $2.64 \%$ respectively, in each category. 6 respondents had an intermediate degree (3.17 percent), 65 respondents had a bachelor's degree (34.39 percent) and the remaining 118 had a masters or higher degree (62.43 percent). 148 respondents represented office employees while the remaining 41 represented ground staff (including engineers and technicians) showing 78.30 and 21.69 percent of each category.

\section{Measures}

All variables of the study were measured through standard instruments developed and validated previously, as discussed in the following sub-sections. Responses on all variables were obtained on likert scale. Negative items were reverse coded.

\section{Breach of Psychological Contract}

The scale of psychological contract breach by Robinson and Morrison (2000) was adopted to measure the perception of employees' perception regarding the organization's fulfillment of its obligations toward them. The scale had 5 items. Sample items include; "Almost all the promises made by my employer during recruitment have been kept so far" and "So far my employer has done an excellent job of fulfilling his/her promises to me". Responses were obtained on a five-point likert scale ranging from "Strongly agree" to "strongly disagree".

\section{Psychosomatic Strain}

Based on Karagonlar, Eisenberger and Aselage (2016) psychosomatic strain was measured on a 7-point scale $(1=$ never, $7=$ very often $)$, where employees were asked how often they experienced the following somatic complaints adapted from prior literature (Caplan, Cobb, Harrison, \& Pinneau, 1980; Frese, 1985; Greller \& Parsons, 1988): "overly tired/lack of energy," "headaches," "sleep problems," "nervous/ tense," "back pain," and "indigestion/acid stomach." Such psychosomatic complaints represent a formative measure where complaints are not interchangeable (i.e., the existence of one complaint is not necessarily associated with the existence of another) (Spector \& Jex, 1998). Spector and Jex (1998) noted that because 
these complaints do not represent an underlying latent construct and rather define the construct themselves, measurement error is irrelevant to such psychosomatic complaint scales, and thus, this scale is not necessarily expected to have high inter-item reliability. Therefore, the low Cronbach's $\alpha(0.6)$ of psychosomatic strain measure does not pose a significant threat to validity.

\section{Quality of life}

The Quality of Life-Brief (WHOQOL-Bref) scale by World Health Organization (WHO) was adopted to measure the respondents' overall quality of life. It is the shorter version of the basic scale of 100 items and contains 26 items in total. It is also the most widely used scale to measure quality of life. The scale has been recently used by Min (2014) and Abdel-Khalek (2010). The scale covers four dimensions of quality of life including physical and psychological health, social relationships and environment. The scale measures QOL using various likert scales for each dimension. Sample items include; "Do you get the kind of support from others that you need?" (Social dimension), "How much do you need any medical treatment to function in your daily life" (physical dimension), "How often do you have negative feelings such as blue mood, despair, anxiety, depression?" (Psychological dimension), "How satisfied are you with the conditions of your living place?" (Environmental dimension).

\section{Power Distance}

Power distance was measured by adopting the scale of Dorfman and Howell (1988). The scale has been recently used by Zagenczyka (2014) in the context of psychological contract breach. The scale had six items obtaining responses on a five-point likert scale ranging from "strongly agree" to "strongly disagree". Sample items are "Managers should make most decisions without consulting subordinates" and "Managers should seldom ask for the opinions of employees".

\section{RESULTS}

The mean, standard deviation, inter-correlations and Cronbach's alpha value of the study variables are presented in table 1. Breach of psychological contract was significantly and positively correlated with psychosomatic strain $(\mathrm{r}=0.17, \mathrm{p}<0.05)$ and had a significant negative correlation with quality of life $(r=-0.25, p<0.01)$, whereas, it was not significantly correlated with power distance $(\mathrm{r}=0.07$, $\mathrm{p}=0.28$ ).Psychosomatic strain had positive significant correlation with power distance $(\mathrm{r}=0.48, \mathrm{p}<0.01)$, and had a negative significant correlation with quality of life ( $\mathrm{r}=$ $-0.49, \mathrm{p}<0.01)$. We found power distance to be negatively correlated with quality of life $(r=-0.49, p<0.01)$. It is pertinent to note that quality of life was found to have negative significant correlation with all the study variables, i.e. breach of psychological contract, psychosomatic strain and power distance $(-0.25,-0.43$ and -0.49$)$, respectively.

Table 2 shows the results of mediation analysis, including the total, direct and indirect effects. Mediation analysis was run using the bootstrapping method by Preacher and Hayes, (2008). With 95\% confidence intervals, 5000 bootstrap re-samples were used for this analysis.

The total effect explains the relationship between the breach of psychological contract and quality of life, which turned out to be -0.13 with no zero value lying between ULCI (-0.06) and LLCI (-0.21). Direct effect represents the impact of breach of psychological contract and psychosomatic strain combined on quality of life. The direct effect turned out to be -0.09 with no zero value lying between ULCI $(-0.02)$ and LLCI $(-0.16)$. The effect size in the presence of the mediating variable i.e. psychosomatic strain turned out to be -0.03 with no zero value lying between ULCI (-0.00) and LLCI (-0.08). Consistent with Preacher and Hayes (2004), the presence of a non-zero value between the upper and lower boot limits demonstrates a significant relationship. Based on these results, it is concluded that breach of psychological contract is negatively associated with employees' quality of life; moreover, psychosomatic strain mediates the said relationship, leading to the acceptance of hypotheses one and two.

TABLE 1

Correlation and reliabilities (in parentheses) matrix of study variables

\begin{tabular}{lcccccc}
\hline Variables & Mean & S.D & $\mathbf{1}$ & $\mathbf{2}$ & $\mathbf{3}$ & $\mathbf{4}$ \\
\hline Breach of psychological contract & 3.50 & 1.06 & $(0.81)$ & & & \\
Psychosomatic strain & 3.43 & 0.69 & $0.17^{*}$ & $(0.60)$ & & \\
Power distance & 3.70 & 0.78 & 0.07 & $0.48^{* *}$ & $(0.90)$ & \\
Quality of life & 3.81 & 0.57 & $-0.25^{* *}$ & $-0.43^{* *}$ & $-0.49^{* *}$ & $(0.90)$ \\
\hline
\end{tabular}

$* p<0.05$

$* * p<0.01$ 
TABLE 2

Mediation analysis

\begin{tabular}{lcccc}
\hline \multicolumn{1}{c}{ Effect } & Effect Size & S.E & LL95\%CI & UL95\%CI \\
\hline Total Effect & -0.13 & 0.03 & -0.21 & -0.06 \\
Direct Effect & -0.09 & 0.03 & -0.16 & -0.02 \\
Indirect Effect & -0.03 & 0.01 & -0.08 & -0.00 \\
\hline
\end{tabular}

$S . E=$ standard error, $L L=$ lower limit, $U L=$ upper limit, $C I=$ confidence interval

A moderation test was also run using the bootstrapping method by Preacher and Hayes (2008). With 95\% confidence intervals, 5000 bootstrap resamples were used for this analysis. Table 3 reports the results of moderation analysis taking power distance as a moderator between psychological contract breach and psychosomatic strain. The resulting value of $\mathrm{R} 2$ Change (0.004) is negligible with insignificant $p$ value of 0.28 . Therefore, hypothesis three has been rejected as power distance does not positively moderate the relationship between psychological contract breach and psychosomatic strain. Figure 2 shows the moderation plot, taking the breach of psychological contract as independent, power distance as moderator and psychosomatic strain as the dependent variables.

TABLE 3

Moderation analysis

\begin{tabular}{ccc}
\hline R2 Change & F & Sig \\
\hline 0.004 & 1.14 & 0.28 \\
\hline
\end{tabular}

FIGURE 2

Moderation plot of power distance between psychological contract breach and psychosomatic strain

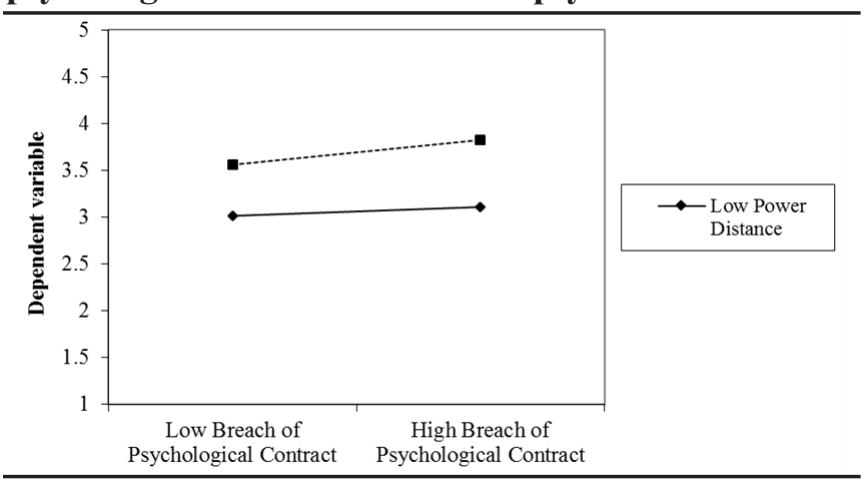

DISCUSSION

The study was aimed at finding out the relationship between the breach of psychological contract and quality of life, through mechanism of psychosomatic strain and moderating effect of power distance. The results are pertinent in explaining the negative effects of psychological contract breach upon employees' wellbeing which was conceptualized as quality of life in the present study. The mediating mechanism through which
BPC leads to decline in quality of life is also identified in the form of psychosomatic strain. Moreover, the moderating effect of power distance between BPC and psychosomatic strain was also tested. As hypothesized, the breach of psychological contract turned out to have a significant negative association with the quality of life of employees experiencing such breach. This explains that the negative effects of BPC go beyond the generally studied workplace outcomes and the feeling of broken promises and non-fulfillment of the obligations by the employer can lead to effect employees' life and well-being as well. This finding is significant, since it establishes a clear link between BPC and quality of life taking all four dimension of QOL which are physical, psychological, social and environment-related. Therefore, this study is consistent with the findings of De Jong et al. (2015) and Cuyper (2008), who gave a broad view that the breach of psychological contract and employee well-being are negatively associated. However, the present findings go beyond a general perspective of well-being and specifically relate the breach of psychological contract with quality of life as an outcome variable.

According to the results, the mediating effect of psychosomatic strain between the breach of psychological contract and quality of life has also been substantiated. It was argued earlier that psychological contract breach can be a workplace stressor causing psychosomatic strain and such strain then becomes a cause of declining quality of life of employees. Therefore, the breach of psychological contract has been confirmed as a workplace stressor, which leads to declining quality of life via psychosomatic strain. It can be inferred that when employees find themselves in a situation where they feel that their employers are not fulfilling their obligations as part of the psychological contract, they experience psychosomatic strain with the symptoms of overly tired/lack of energy," "headaches," "sleep problems," "nervous/tense," "back pain," and "indigestion/acid stomach, as identified by Karagonlar, Eisenberger and Aselage (2016). The path from psychosomatic strain to quality of life also turned out to be negative, implying that such strain not only negatively affects employees' quality of life but also creates a mediating link between the breach of psychological contract and quality of life.

The mediating mechanism can also be viewed from the perspective of affective events theory by Weiss 
\& Cropanzano (1996) which provides the foundation for the study. Affective events theory (AET), predicts and explains that how specific organizational events determine employee attitude and their well-being (Weiss \& Cropanzano, 1996). As discussed earlier that Cropanzano and Mitchell (2005) explained the breach of psychological contract as a negative event according to social exchange theory, which shows an organization's failure to reciprocate employees' contribution. Under such situations, employees start developing the feeling of being betrayed, indicating breach of psychological contract on part of the organization. It creates negative feelings amongst them, which adversely affects their quality of life. In line with affective events theory, it predicts that negative events at workplace cause negative emotions like frustration and anger, ultimately resulting in negative outcomes leading to reduced quality of life; similarly posited by Morrison and Robinson (1997).

The study results show that the moderating role of power distance between the breach of psychological contract and psychosomatic strain has not been substantiated. Pakistani public sector organizations are high on the demission of power distance with centralized and autocratic decision making, highly personalized, strong leadership, limited delegation, bureaucratic controls and little empowerment (Lok \& Crawford, 2004; Joiner, 2001; Fikret, 2000; Robert, 2000). It was argued that under high power distance situations, where employees have very little or no opportunity to communicate their concerns to senior management, such inability to voice their problems can enhance the resulting psychosomatic strain in the scenario where the breach of psychological contract has occurred. This may be attributed to the reason that employees in high power distance cultures generally accept the exercise of power by the people up in the hierarchy as suggested by Hofstede (1983), and they as a part of their national culture and collective programming perceive the exercise of such power by the authorities as legitimate and don't find it rather troubling to keep silent over the issues which affect them.

\section{Implications}

The current study contributes in the exiting literature of psychological contract breach with respect to quality of life through the mediating and moderating mechanisms of psychosomatic strain and power distance. The empirical validation of the negative effects of psychological contract breach upon quality of life is a step towards the identification of the negative side of such breach upon overall quality of life of employees including their physical, psychological, social and environmental aspects. The results further suggest taking the breach of psychological contract as a situation which goes beyond the working life of an individual.

Additionally, the study explains the path through which the breach of psychological contract leads to decline in employees, quality of life. Psychosomatic strain as a mediator between the breach of psychological contract and quality of life turned out to be a potential variable that affects an individual's quality of life negatively. The absence of power distance as a moderator between the breach of psychological contract and psychosomatic strain suggests that power distance does not necessarily increase the negative effects of psychological contract breach, rather it is so deep-rooted in the national and organizational culture that individuals take it as a routine matter to obey the decisions of the authorities whether they are right or wrong.

The study also has noteworthy managerial implications. The breach of psychological contract has been found to adversely affect individual's quality of life, through psychosomatic strain. Therefore, mangers are advised to understand the expectation of their subordinates, so that they can take care of their legitimate concerns. If the managers fail to understand the implicit meaning of the contract that the employees have developed with the employing organization, this could result in psychosomatic strain and the decline in the quality of life. Deteriorating quality of life of employees will eventually have negative consequences for the employees and the organization in the form of illnesses, absenteeism, and lateness, lack of interest, reduced commitment and even actual turnover. Though, power distance has not been found to moderate the relationship between the breach of psychological contract and psychosomatic strain, yet the managers need to listen to the voice of employees, since all employees do not have same personality traits and might not react homogeneously in an environment of silence and suppression.

\section{LIMITATIONS AND FUTURE RESEARCH DIRECTIONS}

Although, the study objectives are successfully attained, still the findings need to be interpreted with caution. First, the sampling technique employed was of purposive sampling based on the willingness of participants; therefore, some participants who could be a suitable source of response may be missed because of their non-participation. Next, the problem of cultural specificity may be a point of concern, because data were collected from Islamabad and Rawalpindi region only. Finally, the findings can't claim to establish a causal relationship between the variables because the study was cross-sectional in nature.

The integration of moderating variables in the relationship of psychosomatic strain and quality of life is 
suggested for better understanding of the dynamics of this relationship. It is suggested that some support variables may moderate the said relationship including supervisory, peer and spousal support. Other suggested moderating variables between the breach of psychological contract and psychosomatic strain are employees' optimism and dispositional factors. Future research in the same context is recommended with a longitudinal design to establish causality of relationship between the variables. A similar study needs to be conducted in private sector with a diverse countrywide sample to increase its generalization and applicability.

\section{REFERENCES}

Abdel-Khalek, A. M. (2010). Quality of life, subjective well-being, and religiosity in Muslim college students. Quality of Life Research, 19(8), 11331143.

Aselage, J., \& Eisenberger, R. (2003). Perceived organizational support and psychological contracts: A theoretical integration. Journal of Organizational Behavior, 24(5), 491-509.

Atkinson, C. (2007). Trust and the psychological contract. Employee Relations, 29(3), 227-246.

Bal, P. M., De Lange, A. H., Jansen, P. G., \& Van Der Velde, M. E. (2008). Psychological contract breach and job attitudes: A meta-analysis of age as a moderator. Journal of Vocational Behavior, 72(1), 143-158.

Barnes, P. W., \& Lightsey, O. R. (2005). Perceived racist discrimination, coping, stress, and life satisfaction. Journal of Multicultural Counseling and Development, 33(1), 48-61.

Bashir, S., \& Nasir, M. (2013). Breach of psychological contract, organizational cynicism and union commitment: A study of hospitality industry in Pakistan. International Journal of Hospitality Management, 34, 61-65.

Bauer, J., Stamm, A., Virnich, K., Wissing, K., Müller, U., Wirsching, M., \& Schaarschmidt, U. (2006). Correlation between burnout syndrome and psychological and psychosomatic symptoms among teachers. International archives of occupational and environmental health, 79(3), 199-204.

Beer, M., \& Eisenstat, R. A. (2000). The silent killers of strategy implementation and learning. MIT Sloan Management Review, 41(4), 29-40.

Bochner, S., \& Hesketh, B. (1994). Power distance, individualism/collectivism, and job-related attitudes in a culturally diverse work group. Journal of Cross-Cultural Psychology, 25(2), 233-257.

Bordia, P., Restubog, S. L. D., \& Tang, R. L. (2008). When employees strike back: investigating mediating mechanisms between psychological contract breach and workplace deviance. Journal of Applied Psychology, 93(5), 1104-1117.

Boreham, P., Povey, J., \& Tomaszewski, W. (2016). Work and social well-being: the impact of employment conditions on quality of life. The International Journal of Human Resource Management, 27(6), 593-611.

Caplan, R. D., Cobb, S., French, J. R. P., Jr., Harrison, R. V., \& Pinneau, S. R. (1980). Job demands and worker health: Maineffects and occupational differences. Ann Arbor: Institute of social research.

Cassar, V., \& Buttigieg, S. C. (2015). Psychological contract breach, organizational justice and emotional well-being. Personnel Review, 44(2), 217-235.

Cella,D.F.(1994). Quality of life: concepts and definition. Journal of Pain and Symptom Management, 9(3), 186-192.

Chao, J. M., Cheung, F. Y., \& Wu, A. M. (2011). Psychological contract breach and counterproductive workplace behaviors: testing moderating effect of attribution style and power distance. The International Journal of Human Resource Management, 22(04), 763-777.

Chiu, S. F., \& Peng, J. C. (2008). The relationship between psychological contract breach and employee deviance: The moderating role of hostile attributional style. Journal of Vocational Behavior, 73(3), 426-433.

Conway, N., \& Briner, R. B. (2002). A daily diary study of affective responses to psychological contract breach and exceeded promises. Journal of Organizational Behavior, 23(3), 287-302.

Costa, A. C., Roe, R. A., \& Taillieu, T. (2001). Trust within teams: The relation with performance effectiveness. European Journal of Work and Organizational Psychology, 10(3), 225-244.

Costanza, R., Fisher, B., Ali, S., Beer, C., Bond, L., Boumans, R., ... \& Gayer, D. E. (2007). Quality of life: An approach integrating opportunities, human needs, and subjective well-being. Ecological Economics, 61(2), 267-276.

Coyle-Shapiro, J., \& Kessler, I. (2000). Consequences of the psychological contract for the employment relationship: A large scale survey*. Journal of Management Studies, 37(7), 903-930.

Cropanzano, R., \& Mitchell, M. S. (2005). Social exchange theory: An interdisciplinary review. Journal of Management, 31(6), 874-900.

Cuyper, N. D., Bernhard-Oettel, C., Berntson, E., Witte, H. D., \& Alarco, B. (2008). Employability and Employees' Well-Being: Mediation by Job Insecurity. Applied Psychology, 57(3), 488-509. 
De Cuyper, N., \& De Witte, H. (2007). Job insecurity in temporary versus permanent workers: Associations with attitudes, well-being, and behaviour.Work \& Stress, 21(1), 65-84.

De Jong, J. D., Clinton, M., Rigotti, T., \& BernhardOettel, C. (2015). Nonlinear associations between breached obligations and employee well-being. Journal of Managerial Psychology, 30(4), 374389.

De Jonge, J., Bosma, H., Peter, R., \& Siegrist, J. (2000). Job strain, effort-reward imbalance and employee well-being: a large-scale cross-sectional study. Social Science \& Medicine, 50(9), 1317-1327.

Diener, E. (2000). Subjective well-being: The science of happiness and a proposal for a national index. American Psychologist, 55(1), 34-43.

Dorfman, P. W., \& Howell, J. P. (1988). Dimensions of national culture and effective leadership patterns: Hofstede revisited. Advances in International Comparative Management, 3(1), 127-150.

Fikret Pasa, S. (2000). Leadership influence in a high power distance and collectivist culture. Leadership \& Organization Development Journal, 21(8), 414426.

Frese, M. (1985). Stress at work and psychosomatic complaints: a causal interpretation. Journal of Applied Psychology, 70(2), 314-328.

Gakovic, A., \& Tetrick, L. E. (2003). Psychological contract breach as a source of strain for employees. Journal of Business and Psychology, 18(2), 235246.

Ganster, D. C., \& Rosen, C. C. (2013). Work stress and employee health A multidisciplinary review. Journal of Management, 0149206313475815.

Greenhaus, J. H., Collins, K. M., \& Shaw, J. D. (2003). The relation between work-family balance and quality of life. Journal of Vocational Behavior, 63(3), 510-531.

Greller, M., \& Parsons, C. K. (1988). Psychosomatic complaints scale of stress: Measure development and psychometric properties. Educational and Psychological Measurement, 48(4), 1051-1065.

Guest, D. E. (2004). The psychology of the employment relationship: An analysis based on the psychological contract. Applied Psychology, 53(4), 541-555.

Hamarat, E., Dennis, T, Karen M. Zabrucky, Don, S., Kenneth B. Matheny, B., Ferda A. (2001). Perceived stress and coping resource availability as predictors of life satisfaction in young, middle-aged, and older adults. Experimental aging Research, 27(2), 181-196.

Hayes, C. T., \& Weathington, B. L. (2007). Optimism, stress, life satisfaction, and job burnout in restaurant managers. The Journal of Psychology, 141(6), 565-
579.

Hofstede, G. (1983). The cultural relativity of organizational practices and theories. Journal of International Business Studies, 14(2), 75-89.

Höge, T. (2009). When work strain transcends psychological boundaries: An inquiry into the relationship between time pressure, irritation, workfamily conflict and psychosomatic complaints. Stress and Health, 25(1), 41-51.

Hui, C., Lee, C., \& Rousseau, D. M. (2004). Psychological contract and organizational citizenship behavior in China: investigating generalizability and instrumentality. Journal of Applied Psychology, 89(2), 311-321.

Islam, N. (2004). Sifarish, sycophants, power and collectivism: Administrative culture in Pakistan. International Review of Administrative Sciences, 70(2), 311-330.

Johnson, J.L., \& O'Leary-Kelly, A. M.(2003). The effects of psychological contract breach and organizational cynicism: Not all social exchange violations are created equal. Journal of Organizational Behavior, 24(5), 627-647.

Joiner, T. A. (2001). The influence of national culture and organizational culture alignment on job stress and performance: evidence from Greece. Journal of Managerial Psychology, 16(3), 229-242.

Karagonlar, G., Eisenberger, R., \& Aselage, J. (2016). Reciprocation wary employees discount psychological contract fulfillment. Journal of Organizational Behavior, 37(1), 23-40.

Khilji, E. (2002). Modes of convergence and divergence: An integrative view of multinational practices in Pakistan. International Journal of Human Resource Management, 13(2), 232-253.

Khilji, S. E. (2004). Whither tradition? Evidence of generational differences in HR satisfaction from Pakistan. International Journal of Cross Cultural Management, 4(2), 141-156.

Kickul, J., \& Lester, S. W. (2001). Broken promises: Equity sensitivity as a moderator between psychological contract breach and employee attitudes and behavior. Journal of Business and Psychology, 16(2), 191-217.

Kickul, J., Lester, S. W., \& Belgio, E. (2004). Attitudinal and behavioral outcomes of psychological contract breach a cross cultural comparison of the United States and Hong Kong Chinese. International Journal of Cross Cultural Management, 4(2), 229252.

Kiefer, T. (2005). Feeling bad: Antecedents and consequences of negative emotions in ongoing change. Journal of Organizational Behavior, 26(8), 875-897. 
Kirkman, B. L., Lowe, K. B., \& Gibson, C. B. (2006). A quarter century of culture's consequences: A review of empirical research incorporating Hofstede's cultural values framework. Journal of International Business Studies, 37(3), 285-320.

Lerner, D. J., Levine, S., Malspeis, S., \& D'Agostino, R. B. (1994). Job strain and health-related quality of life in a national sample. American Journal of Public Health, 84(10), 1580-1585.

Lewis, J. D., \& Weigert, A. (1985). Trust as a social reality. Social Forces, 63(4), 967-985.

Liu, C., Yang, L. Q., \& Nauta, M. M. (2013). Examining the mediating effect of supervisor conflict on procedural injustice-job strain relations: The function of power distance. Journal of Occupational Health Psychology, 18(1), 64-74.

Lok, P., \& Crawford, J. (2004). The effect of organisational culture and leadership style on job satisfaction and organisational commitment: A cross-national comparison. Journal of Management Development, 23(4), 321-338.

Marum, G., Clench-Aas, J., Nes, R. B., \& Raanaas, R. K. (2014). The relationship between negative life events, psychological distress and life satisfaction: a population-based study. Quality of Life Research, 23(2), 601-611.

Matthijs Bal, P., Chiaburu, D. S., \& Jansen, P. G. (2010). Psychological contract breach and work performance: Is social exchange a buffer or an intensifier?. Journal of Managerial Psychology, 25(3), 252-273.

Milliken, F. J., Morrison, E. W., \& Hewlin, P. F. (2003). An exploratory study of employee silence: Issues that employees don't communicate upward and why. Journal of Management Studies, 40(6), 14531476.

Min, J. (2014). The relationships between emotional intelligence, job stress, and quality of life among tour guides. Asia Pacific Journal of Tourism Research, 19(10), 1170-1190.

Morrison, E. W., \& Robinson, S. L. (1997). When employees feel betrayed: A model of how psychological contract violation develops. Academy of management Review, 22(1), 226-256.

Nieuwenhuijsen, K., Bruinvels, D., \& Frings-Dresen, M. (2010). Psychosocial work environment and stress-related disorders, a systematic review. Occupational Medicine, 60(4), 277-286.

Parzefall, M. R., \& Hakanen, J. (2010). Psychological contract and its motivational and health-enhancing properties. Journal of Managerial Psychology, 25(1), 4-21.

Persson, S., \& Wasieleski, D. (2015). The seasons of the psychological contract: Overcoming the silent transformations of the employer-employee relationship. Human Resource Management Review, 25(4), 368-383.

Priesemuth, M., \& Taylor, R. M. (2016). The more I want, the less I have left to give: The moderating role of psychological entitlement on the relationship between psychological contract violation, depressive mood states, and citizenship behavior. Journal of Organizational Behavior, 37(7), 967982.

Restubog, S. L. D., Bordia, P., \& Tang, R. L. (2006). Effects of psychological contract breach on performance of IT employees: The mediating role of affective commitment. Journal of Occupational and Organizational Psychology, 79(2), 299-306.

Restubog, S. L. D., Bordia, P., \& Tang, R. L. (2007). Behavioural Outcomes of Psychological Contract Breach in a Non-Western Culture: The Moderating Role of Equity Sensitivity. British Journal of Management, 18(4), 376-386.

Restubog, S. L. D., Zagenczyk, T. J., Bordia, P., Bordia, S., \& Chapman, G. J. (2015). If you wrong us, shall we not revenge? Moderating roles of self-control and perceived aggressive work culture in predicting responses to psychological contract breach. Journal of Management, 41(4), 1132-1154.

Rigotti, T. (2009). Enough is enough? Threshold models for the relationship between psychological contract breach and job-related attitudes. European Journal of Work and Organizational Psychology, 18(4), 442-463.

Robert, C., Probst, T. M., Martocchio, J. J., Drasgow, F., \& Lawler, J. J. (2000). Empowerment and continuous improvement in the United States, Mexico, Poland, and India: predicting fit on the basis of the dimensions of power distance and individualism. Journal of Applied Psychology, 85(5), 643-658.

Robinson, S. L., \& Morrison, E. W. (2000). The development of psychological contract breach and violation: A longitudinal study. Journal of Organizational Behavior, 21(5), 525-546.

Robinson, S. L., Kraatz, M. S., \& Rousseau, D. M. (1994). Changing obligations and the psychological contract: A longitudinal study. Academy of Management Journal, 37(1), 137-152.

Rousseau, D. M. (1989). Psychological and implied contracts in organizations. Employee Responsibilities and Rights Journal, 2(2), 121139.

Rousseau,D.M.(1998). The problem ofthepsychological contract considered. Journal of Organizational Behavior, 19(1), 665-671.

Rousseau, D. M. (2001). Schema, promise and mutuality: 
The building blocks of the psychological contract. Journal of Occupational and Organizational Psychology, 74(4), 511-541.

Silla, I., De Cuyper, N., Gracia, F. J., Peiró, J. M., \& De Witte, H. (2009). Job insecurity and well-being: Moderation by employability. Journal of Happiness Studies, 10(6), 739-751.

Sonnentag, S., \& Zijlstra, F. R. (2006). Job characteristics and off-job activities as predictors of need for recovery, well-being, and fatigue. Journal of Applied Psychology, 91(2), 330-350.

Spector, P. E., \& Jex, S. M. (1998). Development of four self-report measures of job stressors and strain: interpersonal conflict at work scale, organizational constraints scale, quantitative workload inventory, and physical symptoms inventory. Journal of Occupational Health Psychology, 3(4), 356-367.

Suazo, M. M., \& Stone-Romero, E. F. (2011). Implications of psychological contract breach: A perceived organizational support perspective. Journal of Managerial Psychology, 26(5), 366-382.

Suazo, M. M., Turnley, W. H., \& Mai, R. R. (2005). The role of perceived violation in determining employees' reactions to psychological contract breach. Journal of Leadership \& Organizational Studies, 12(1), 24-36.

The PIA controversy | Pakistan Today. (December, 2015). Retrieved March 24, 2016, from http:// www.pakistantoday.com.pk/2015/12/08/comment/ the-pia-controversy/

Thomas, D. C., Au, K., \& Ravlin, E. C. (2003). Cultural variation and the psychological contract. Journal of Organizational Behavior, 24(5), 451-471.

Troman, G. (2000). Teacher stress in the low-trust society. British Journal of Sociology of Education, 21(3), 331-353.

Weiss, H. M., \& Beal, D. J. (2005). Reflections on affective events theory. Research on Emotion in Organizations, 1(1), 1-21.

Weiss, H. M., \& Cropanzano, R. (1996). Affective events theory: A theoretical discussion of the structure, causes and consequences of affective experiences at work. Research in organizational behavior: An annual series of analytical essays and critical reviews, 8, 1-74.

Westwood, R., Sparrow, P., \& Leung, A. (2001). Challenges to the psychological contract in Hong Kong. International Journal of Human Resource Management, 12(4), 621-651.

Yang, X., Ge, C., Hu, B., Chi, T., \& Wang, L. (2009). Relationship between quality of life and occupational stress among teachers. Public Health, 123(11), 750-755.

Zagenczyk, T. J., Cruz, K. S., Cheung, J. H., Scott, K. L., Kiewitz, C., \& Galloway, B. (2015). The moderating effect of power distance on employee responses to psychological contract breach. European Journal of Work and Organizational Psychology, 24(6), 853-865.

Zhao, H. A. O., Wayne, S. J., Glibkowski, B. C., \& Bravo, J. (2007). The impact of psychological contract breach on work-related outcomes: a metaanalysis. Personnel Psychology, 60(3), 647-680.

Zhao, J., \& Chen, L. (2008). Individualism, collectivism, selected personality traits, and psychological contract in employment: A comparative study. Management Research News, 31(4), 289-304. 